\begin{tabular}{|c|c|c|}
\hline $\begin{array}{l}\text { OPEN ACCESS } \\
\text { Vol. } 4 \text { No. 2: } 47-57 \\
\text { Tahun } 2021 \\
\text { Artikel penelitian 唒 }\end{array}$ & $\begin{array}{l}\text { Eurros: 2598-8204 } \\
\text { http://ojs.umrah.ac.id/index.php/akuatiklestari } \\
\text { DOI: https://doi.org/10.31629/akuatiklestari.v4i2.2536 }\end{array}$ & $\frac{\vdots}{a=}$ \\
\hline
\end{tabular}

\title{
Inventarisasi Ikan Demersal dan Ikan Pelagis yang Didaratkan di PPI Kijang Kecamatan Bintan Timur Kabupaten Bintan
}

\author{
Inventarisation of Demersal Fish and Pelagic Fish Landed at PPI Kijang, Bintan Timur District, \\ Bintan Regency
}

\section{Eflin Krismasia Lubis ${ }^{1}{ }^{\bowtie}$, Theresia Yesika Sinaga ${ }^{1}$, Susiana ${ }^{1}$}

1 Manajemen Sumberdaya Perairan, Fakultas Ilmu Kelautan dan Perikanan, Universitas Maritim Raja Ali Haji, Tanjungpinang, Indonesia 29111

\section{VInfo Artikel:}

Diterima: 21 September 2020

Revisi: 20 Oktober 2020

Disetujui: 27 Mei 2021

Dipublikasi: 30 Mei 2021

\section{Geyword:}

PPI Kijang, Ikan Demersal, Ikan Pelagis, Kabupaten Bintan

\begin{abstract}
ABSTRAK. Ikan merupakan sumber protein hewani yang dibutuhkan oleh manusia disamping daging. Jenis ikan yang pada umumnya ditangkap untuk dijadikan konsumsi baik dalam bentuk segar maupun olahan adalah jenis ikan pelagis dan ikan demersal. Penelitian ini bertujuan untuk mengetahui jenis jenis ikan demersal dan ikan pelagis yang didaratkan di PPI Kijang. Metode penelitian dilakukan melalui survey lapang dan pengumpulan data primer dan sekunder yang didapatkan melalui nelayan dan petugas PPI Kijang. Hasil penelitian terdapat 7 jenis ikan demersal, diantaranya : Ikan delah (Caesio teres), Ikan kurisi (Nemipterus nemurus), Ikan pari (Neotrygon kuhlii), Ikan manyung (Netuma thalassina), Ikan lebam (Siganus guttatus), Ikan jebung (Abalistes stellaris), dan Ikan sebelah (Psettodes erumei). Untuk ikan pelagis terdapat untuk 7 jenis, diantaranya : Ikan Selar (Atule mate), Ikan Kuwe (Gnathanodon speciosus), Ikan Bulat (Carangoides plagiotaenia), Ikan Tongkol (Euthynnus affinis), Ikan Tenggiri (Scomberomorus comerson), Ikan Kembung (Rastrelliger kanagurta), dan Ikan Selar Tetengkek (Megalaspis cordyla).
\end{abstract}

\begin{abstract}
Fish is a source of animal protein needed by humans aside from meat. The types of fish that are generally caught for consumption, both fresh and processed, are pelagic fish and demersal fish. This study aims to determine the types of demersal fish and pelagic fish landed in the Kijang PPI. The research method was carried out through field surveys then primary and econdary data collection obtained through fishermen and PPI Kijang officers. The results of the study were 7 types of demersal fish, including: Yellow and blueback fusilier (Caesio teres), Redspine threadfin bream (Nemipterus nemurus), stingray (Neotrygon kuhlii), giant catfish (Netuma thalassina), rabitfish (Siganus guttatus), starry triggerfish (Abalistes stellaris), and flatfish (Psettodes erumei). And 7 types of pelagic fish, including: Yellow stripe scad (Atule mate), Giant trevally (Gnathanodon speciosus), Roundwhite Fish (Carangoides plagiotaenia), Mackerel tuna (Euthynnus affinis), Narrow-barred spanish mackerel (Scomberomorus comerson), Indian mackerel (Rastrelliger kanagurta), Torpedo scad (Megalaspis cordyla).
\end{abstract}

瞄 How to cite this article:

Lubis, E.K., Sinaga, T.Y., \& Susiana. (2021). Inventarisasi Ikan Damersal dan Ikan Pelagis yang Didaratkan di PPI Kijang Kecamatan Bintan Timur Kabupaten Bintan. Jurnal Akuatiklestari, 4(2): 47-57. DOI: https://doi.org/10.31629/akuatiklestari.v4i2.2536

\section{PENDAHULUAN}

Kabupaten Bintan adalah salah satu kabupaten yang berada di ProvinsiKepulauan Riau yang memiliki memiliki 240 buah pulau baik pulau besar maupun pulau kecil. Hal ini menunjukkan bahwasannya Kabupaten Bintan sangat potensial dikarenakan memiliki sumberdaya pesisir dan laut yang melimpah. Secara geografis, wilayah Kabupaten Bintan terletak antara $130^{\circ} 00^{\prime}$ Bujur Timur 108 $20^{\prime}$ Lintang Selatan $104^{\circ}$ Lintang Utara 1 Bujur Timur. Secara keseluruhan luas wilayah Kabupaten Bintan adalah $87.411,92 \mathrm{~km}^{2}$ terdiri atas wilayah daratan seluas 1.319,51 km² (1,50\%) dan wilayah laut seluas 86.092,41 km²(98,50\%) (RPJMD Kabupaten Bintan Tahun 2016-2021).

Pangkalan Pendaratan Ikan (PPI) memiliki arti penting bagi perekonomian masyarakat yang mayoritas berprofesi sebagai nelayan. PPI Kijang ini merupakan satu-satunya tempat pendaratan ikan yang resmi didirikan oleh Dinas Kelautan dan Perikanan Kabupaten Bintan. Fungsi utamanya adalah sebagai tempat pelayanan untuk memperlancar aktivitas jual beli ikan antara nelayan dan pedagang.

Ikan merupakan sumber protein hewani yang dibutuhkan oleh manusia disamping daging. Tingginya nilai protein yang dimiliki ikan menyebabkan masyarakat banyak di dalam negeri maupun di luar negeri menggemari ikan untuk 
dikonsumsi sehari-hari. Hal ini dibuktikan oleh tingginya minat para pedagang untuk mengekspor ikan keluar negeri maupun sebagai ikan-ikanh ias yang dipelihara oleh masyarakat baik usaha pertambakan tradisional maupun modern (Rosmatun et al., 1997). Jenis ikan yang pada umumnya ditangkap untuk dijadikan konsumsi baik dalam bentuk segar maupun olahan adalah jenis ikan pelagis dan ikan demersal. Penelitian ini bertujuan untuk mengetahui jenis jenis ikan demersal dan ikan pelagis yang didaratkan di PPI Kijang, Kecamatan Bintan Timur, Kabupaten Bintan. Adapun manfaat dalam penelitian ini adalah hasil penelitian ini diharapkan dapat memberikan informasi tentang jenis-jenis ikan demersal dan ikan pelagis hasil tangkapan nelayan yang ada di PPI Kijang, Kecamatan Bintan Timur, Kabupaten Bintan.

\section{BAHAN DAN METODE}

\subsection{Waktu dan Tempat}

Penelitian ini dilaksanakan pada bulan April-Mei 2020 bertempat di Pangkalan Pendaratan Ikan (PPI) Kijang, Kecamatan Bintan Timur, Kabupaten Bintan Provinsi Kepulauan Riau. Yang disajikan pada Gambar $\mathbf{l}$.

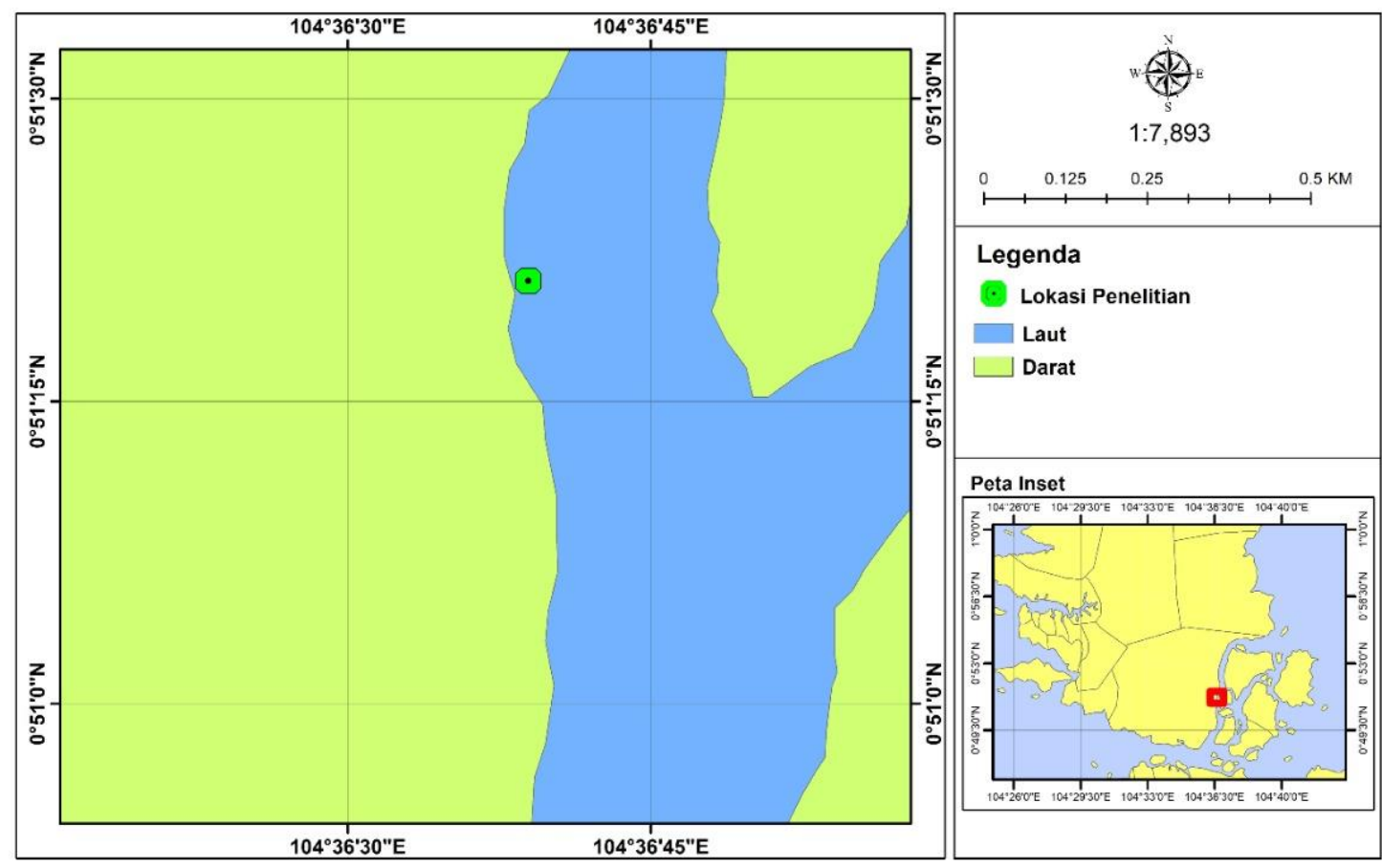

Gambar 1. Peta Lokasi Penelitian

\subsection{Alat dan Bahan}

Alat yang digunakan pada penelitian ini yaitu alat tulis untuk mencatat data yang diambil dari lokasi penelitian dan kamera untuk dokumentasi. Sedangkan bahan yang digunakan yaitu ikan demersal dan ikan pelagis sebagai objek penelitian.

\subsection{Prosedur Penelitian}

Tahapan penelitian ini terdiri dari penentuan lokasi penelitian, pengambilan data, serta pengolahan dan analisis data. Penelitian ini dilakukan melalui survey lapang. Penentuan lokasi penelitian dilakukan di PPI Kijang.

\subsection{Teknik Pengumpulan Data}

Teknik pengumpulan data pada penelitian ini dilakukan melalui survey lapangan ke PPI Kijang. Selanjutnya melakukan wawancara kenelayan, dan petugas di PPI Kijang untuk mendapatkan informasi berupa hasil tangkapan ikan demersal dan ikan pelagis (Zahra et al., 2019).

\subsection{Analisis Data}

Data yang telahdikumpulkan baik data primer maupun data sekunder, ditampilkan dalam bentuk deskripsi. Setelah deskripsi data didapatkan informasi mengenai jenis-jenis ikan demersal dan ikan pelagis yang ada di Pangkalan Pendaratan Ikan Kijang kecamatan Bintan Timur Kabupaten Bintan. Informasi yang di dapatkan berupa nama umum ikan, nama ilmiah ikan dan gambaran morfologi dari ikan demersal dan ikan pelagis yang ada di PPI Kijang. Data jenis ikan yang ada di PPI Kijang berikutnya akan diidentifikasi dengan menggunkan web fishbase.org. 


\section{HASIL DAN PEMBAHASAN}

\subsection{Keadaan Umum Wilayah Penelitian}

Pangkalan pendaratan ikan yang dipakai sebagai tempat penelitian terletak di PPI Kijang, Pasar Barek Motor, Kijang, Kecamatan Bintan Timur, Kabupaten Bintan, Kepulauan Riau. Di PPI Kijang, Pasar Barek Motor terdapat beberapa gudang hasil tangkapan nelayan dari berbagai wilayah penangkapan didaratkan di gudang-gudang tersebut. Ikan yang di daratkan di gudang tersebut, dijual ke berbagai tempat misalnya pasar ikan. Keadaan cuaca wilayah Kijang dipengaruhi oleh angin utara, timur, barat, dan selatan. Musim angin utara ditandai angin kencang dan gelombang laut yang besar sehingga nelayan tidak melaut.

\subsection{Hasil Pengamatan Ikan Demersal}

Hasil pengamatan ikan demersal yang ditemukan pada PPI Kijang antara lain, Ikan Delah (Caesio teres) dapat dilihat pada Gambar 2. Ikan Kurisi (Nemipterus nemurus) dapat dilihat pada Gambar 3. Ikan Pari (Neotrygon kuhlii) dapat dilihat pada Gambar 4. Ikan Manyung (Netuma thalassina) dapat dilihat pada Gambar 5. Ikan Lebam (Siganus gutattus) dapat dilihat pada Gambar 6. Ikan Jebung (Abalistes stellaris) dapat dilihat pada Gambar 7. Serta, Ikan Sebelah (Psettodes euremei) dapat dilihat pada Gambar 8.

\subsubsection{Ikan Delah (Caesio teres)}

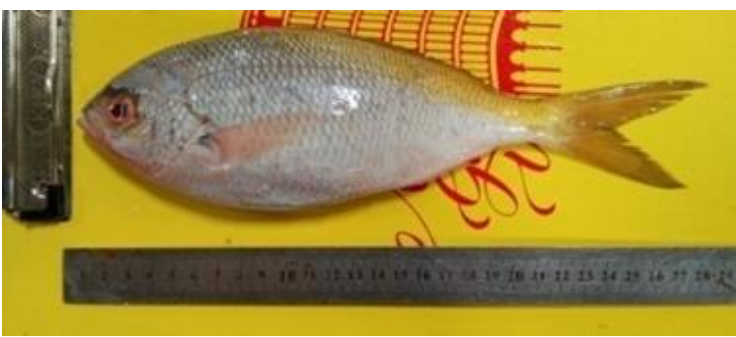

(a)

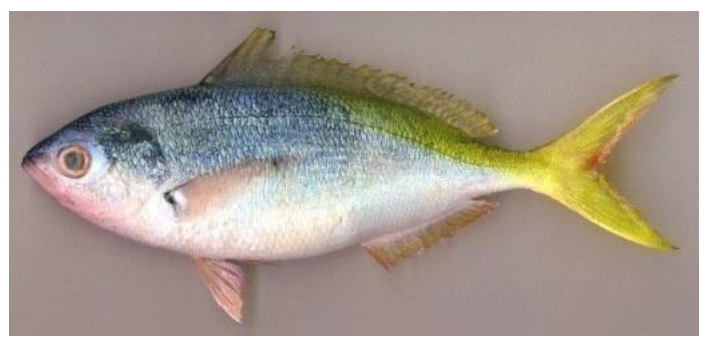

(b)

Gambar 2. Ikan Delah (Caesio teres) : (a) Gambar Pengamatan (b) Gambar dari fishbase.org

Klasifikasi ikan delah menurut fishbase adalah sebagai berikut :

$\begin{array}{ll}\text { Kingdom } & \text { : Animalia } \\ \text { Filum } & \text { : Chordata } \\ \text { Kelas } & \text { : Actinopterygii } \\ \text { Ordo } & \text { : Perciformes } \\ \text { Famili } & : \text { Caesionidae } \\ \text { Genus } & : \text { Caesioniae } \\ \text { Spesies } & : \text { Caesio teres }\end{array}$

Berdasarkan hasil penelitian didapatkan bahwa tubuh bagian punggung berwarna kuning, biru menyala sisi. Dengan bentuk tubuh compressed, bentuk ekor cagak, sedangkan bentuk mulut terminal. Ekor ikan delah berbentuk cagak.Sirip dada, sirip perut dan dubur berwarna putih; sirip punggung berwarna kebiru - biruan dan kuning (Desriani et al., 2019)

Menurut Carpenter (1988), menyatakan bahwa ikan delah memiliki gigi kecil pada rahang mulut. Sirip punggung dengan 10 duri dan 15, sinar lunak; sirip dubur dengan 3 duri dan sinar lunak; sirip dada biasanya dengan jumlah 20 hingga 22, sirip dubur biasanya 17 hingga 20; 4 atau 5 baris sisik pada pipi, sisik predorsal biasanya 21 hingga 25 .

\subsubsection{Ikan Kurisi (Nemipterus nemurus)}

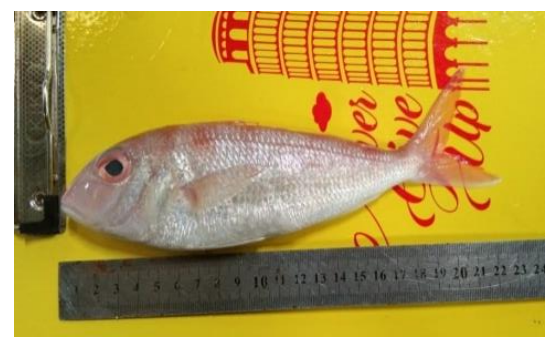

(a)

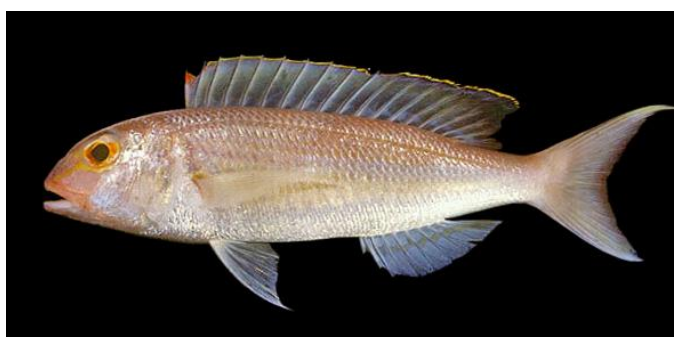

(b)

Gambar 3. Ikan Kurisi (Nemipterus nemurus) : (a) Gambar Pengamatan (b) Gambar dari Fishbase.Org

Klasifikasi ikan kurisi menurut fishbase adalah sebagai berikut :

Kingdom : Animalia 


$\begin{array}{ll}\text { Filum } & : \text { Chordata } \\ \text { Kelas } & : \text { Pisces } \\ \text { Ordo } & : \text { Percomorphi } \\ \text { Famili } & : \text { Nemipteridae } \\ \text { Genus } & : \text { Nemipterus } \\ \text { Spesies } & : \text { Nemipterus nemurus }\end{array}$

Ikan kurisi (Nemipteridae) tergolong ke kelompok ikan demersal yang memiliki salah satu sifat beruaya yang tidak terlalu jauh dan aktivitas gerak yang relatif rendah. Sifat ini yang mengakibatkan daya tahan ikan kurisi rendah terhadap tekanan penangkapan. Ukuran ikan yang tertangkappun cenderung semakin kecil (Triharyuni et al., 2013).

Rahayu (2012) menyatakan bahwa, ikan kurisi dapat ditandai dengan bentuk mulut yang letaknya agak kebawah dan adanya sungut yang terletak didagunya yang digunakan untuk meraba sebagai cara pencarian makanan. Tipe mulut tergolong terminal, mempunyai bentuk gigi kecil membujur dan gigi taring pada rahang atas. Ikan kurisi sendiri berukuran kecil, badan langsing, memanjang dan padat. Bagian depan kepala ikan ini tidak bersisik. Sisik dimulai dari pinggiran depan mata dan keping tutup insang. dan lubang hidung terletak di kedua sisi moncong, berdekatan satu sama lain. Ikan ini memiliki tubuh berwarna merah ke kuning-kuningan.

\subsubsection{Ikan Pari (Neotrygon kuhlii)}

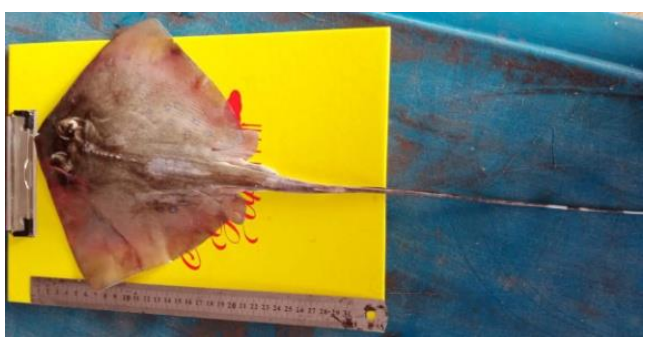

(a)

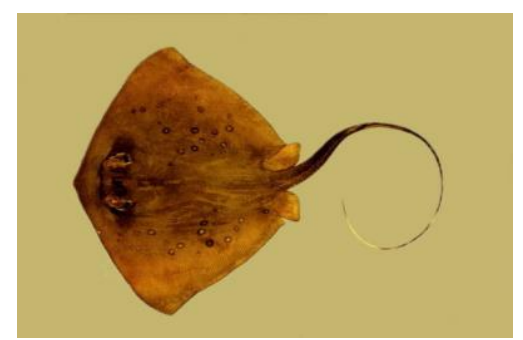

(b)

Gambar 4. Ikan Pari (Neotrygon kuhlii): (a) Gambar Pengamatan (b) Gambar dari fishbase.org

Klasifikasi ikan pari menurut fishbase adalah sebagai berikut :

$\begin{array}{ll}\text { Kingdom } & \text { : Animalia } \\ \text { Filum } & \text { : Chordata } \\ \text { Kelas } & \text { :Chondrischtyes } \\ \text { Ordo } & : \text { Myliobatiformes } \\ \text { Famili } & : \text { Dasyatidae } \\ \text { Genus } & \text { : Neotrygoninae } \\ \text { Spesies } & : \text { Neotrygon kuhlii }\end{array}$

Pada beberapa jenis Pari, duri tajam tersebut terdapat di bagian ventral dan dorsal (Puckridge et al., 2013). Keberadaan duri tajam yang dapat membuat Pari disebut sebagai ikan Sting Rays atau ikan Duri Penyengat. Pari akan melukai lawannya atau melumpuhkan mangsanya dalam keadaaan terancam, yang dimana dapat menyebabkan kematian.

Bersarkan hasil yang didapatkan ikan pari memiliki bentuk tubuh berupa lempengan dengan bentuk kepala membulat disebut depressed, moncong pendek dengan sudut melebar. Terdapat bintik-bintik hitam yang menyebar melintang melewati mata. Warna tubuhnya coklat kemerahan dengan beberapa bintik-bintik biru dan terkadang hitam pada bagian punggung atau dorsal. Bentuk mulutnya terminal, dengan posisi di bagian bawah tubuh.b Menurut Kinakesti et al. (2017), mengatakan bahwa Pari jenis Neotrygon kuhlii mempunyai lempengan kepala dengan panjang $40 \mathrm{~cm}$ dan lebar $21,5 \mathrm{~cm}$.

\subsubsection{Ikan Manyung (Netuma thalassina)}

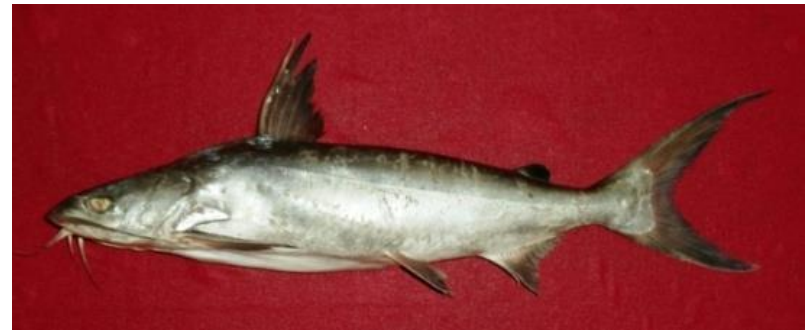

(a)

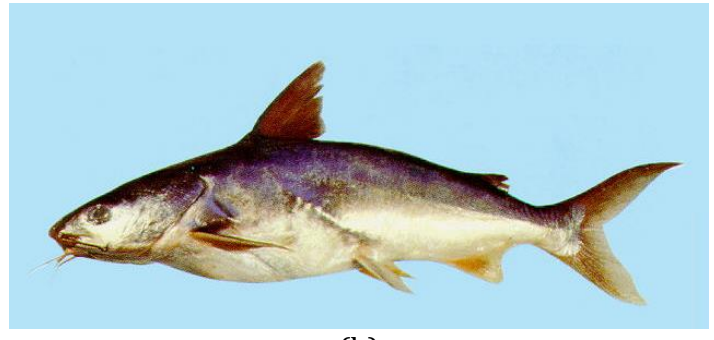

(b)

Gambar 5. Ikan Manyung (Netuma thalassina) : (a) Gambar pengamatan (b) Gambar dari fishbase.org 
Klasifikasi ikan manyung menurut fishbase adalah sebagai berikut :

$\begin{array}{ll}\text { Kingdom } & \text { :Animalia } \\ \text { Filum } & \text { :Chordata } \\ \text { Kelas } & \text { :Actinopterygii } \\ \text { Ordo } & \text { :Ostariophysis } \\ \text { Famili } & : \text { Ariidae } \\ \text { Genus } & \text { : Ariinae } \\ \text { Spesies } & \text { :Netuma thalassina }\end{array}$

Ikan Manyung (Netuma thalassina) merupakan salah satu ikan dasar (demersal) yang memiliki potensi ekonomis penting, tergolong dalam family Ariidae (Marceniuk \& Naircio, 2007 dalam Taunay et al., 2013). Berdasarkan hasil penelitian yang didapatkan kepala ikan manyung berbentuk depress dan badan berbentuk kompress, tubuhnya tidak memiliki sisik, sirip punggung berjari-jari keras dan tajam, mulut tidak dapat disembulkan, mempunyai empat pasang sungut, sirip ekor bercagak, dan memiliki sirip tambahan yang terletak di belakang sirip dorsal, untuk warna tubuh berwarna merah sawo, putih dan merah maya-maya bagian bawah.

Menurut Febriyanti (2015) mengatakan bahwa ikan manyung dapat ditandai dengan ciri utama yang terdapat pada sirip belakang dengan tambahan sirip berupa lemak yang terletak dibelakanng sirip dorsal dan tidak saling berhubungan. Pada bagian sirip dada, punggung, dan bagian dubur masing masing berjari keras satu dan mengandung racun atau bisa.

\subsubsection{Ikan Lebam (Siganus gutattus)}

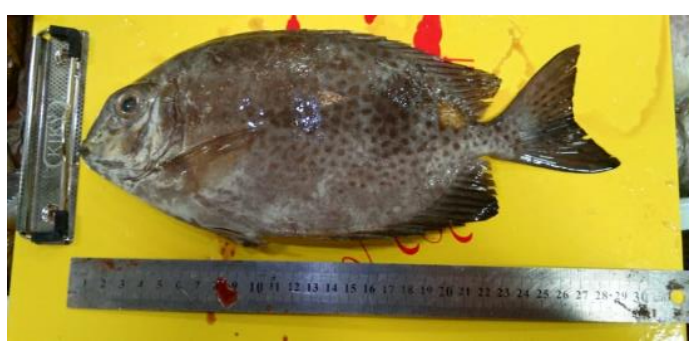

(a)

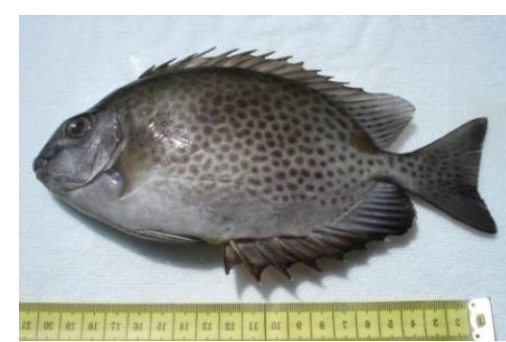

(b)

Gambar 6. Ikan Lebam (Siganus guttatus): (a) Gambar Pengamatan (b) Gambar dari fishbase.org

Klasifikasi ikan lebam menurut fishbase adalah sebagai berikut :

$\begin{array}{ll}\text { Kingdom } & : \text { Animalia } \\ \text { Filum } & : \text { Chordata } \\ \text { Kelas } & : \text { Pisces } \\ \text { Ordo } & : \text { Perciformes } \\ \text { Famili } & : \text { Siganidae } \\ \text { Genus } & : \text { Siganus } \\ \text { Spesies } & : \text { Siganus guttatus }\end{array}$

Amalsyah et al. (2019), menyatakanIkan lebam atau juga sering disebut ikan baronang totol (S. guttatus) termasuk dalam family Siganidae, merupakan ikan demersal yang hidup di dasar atau dekat dengan dasar perairan. Ikan ini banyak ditemukan di daerah padang lamun dan terumbu karang. Siganidae merupakan ikan herbivora. Ikan baronang S. Guttatus sesuai dengan morfologis dari gigi dan saluran pencernaannya yaitu ukuran mulut yang kecil, dinding lambung agak tebal, usus halus panjang dan mempunyai permukaan yang luas sehingga ikan ini digolongkan sebagai ikan herbivora.

Berdasarkan hasil yang di dapat ikan lebam memiliki badan berbentuk pipih atau sering disebut compressed. Bentuk mulutnya yaitu terminal. Sekujur tubuh di penuhi dengan bercak-bercak berwarna coklat. Ekor ikan lebam berbentuk cagak. Badan bagian bawah ikan ini berwarna abu-abu. Ikan ini memiliki sisik di sekitar tubuhnya dan sirip pada perutnya.

\subsubsection{Ikan Jebung (Abalistes stellaris)}

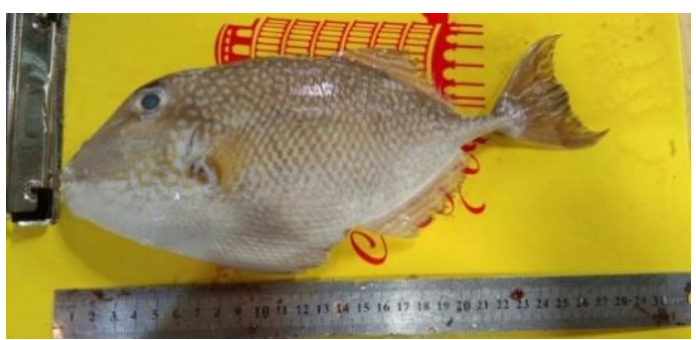

(a)

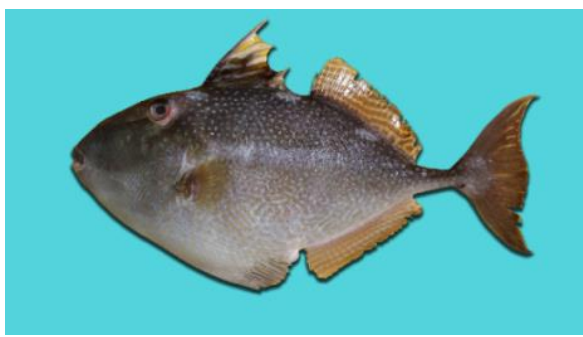

(b) 
Gambar 7. Ikan Jebung (Abalistes stellaris) : (a) Gambar Pengamatan (b) Gambar dari fishbase.org

Klasifikasi ikan jebung menurut fishbase adalah sebagai berikut :

$\begin{array}{ll}\text { Kingdom } & \text { : Animalia } \\ \text { Filum } & \text { : Chordata } \\ \text { Kelas } & \text { : Actinopterygii } \\ \text { Ordo } & \text { :Tetraodontiformes } \\ \text { Famili } & : \text { Balistidae } \\ \text { Genus } & : \text { Abalistes } \\ \text { Spesies } & : \text { Abalistes stellaris }\end{array}$

Zarry et al. (2017) menyatakan bahwasannya Ikan Jebong (Abalistes stellaris) (Bloch dan Schneider, 1801) merupakan salah satu spesies ikan yang berasal dari family Balistidae. Spesies ikan ini dapat ditemukan di Indo-Pasifik (Laut Merah dan Afrika Timur ke Asia Tenggara, utara ke Jepang dan selatan ke utara Australia, serta timur Atlantik bagian barat)

Berdasarkan hasil yang di dapatkan warna tubuh ikan ini coklat kekuning-kuningan, dibagian perut berwarna putih. Sisik tubuh pada ikan jebung posterior dengan menonjol, membentuk punggung dengan bentuk longitudinal; sirip ekor ikan dewasa memanjang atas dan bawah; sisik berukuran besar pada bagian atas sirip pektoral; memakan hewan bentik; termasuk ikan oviparous. Mulut terminal; gigi meruncing. Sirip ekor berpinggiran berlekuk ganda. Ikan ini pada umumnya memiliki panjang $40 \mathrm{~cm}$ dan panjang maksimum $60 \mathrm{~cm}$. Sirip dorsal terdapat 3 jari-jari keras dan 2527 jari-jari lemah; sirip anal 0 jari-jari keras dan jari-jari lemah berjumlah 24-26; jari-jari sirip dada 15-16.

\subsubsection{Ikan Sebelah (Psettodes euremei)}

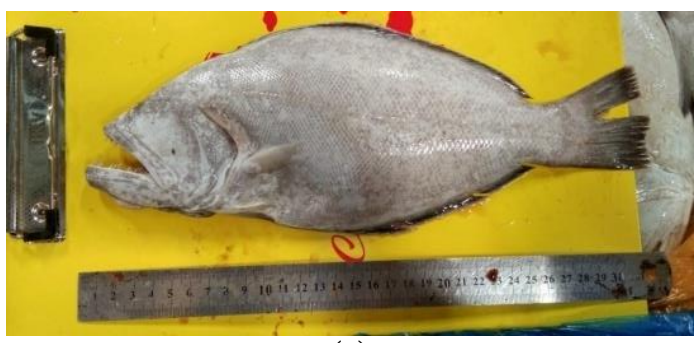

(a)

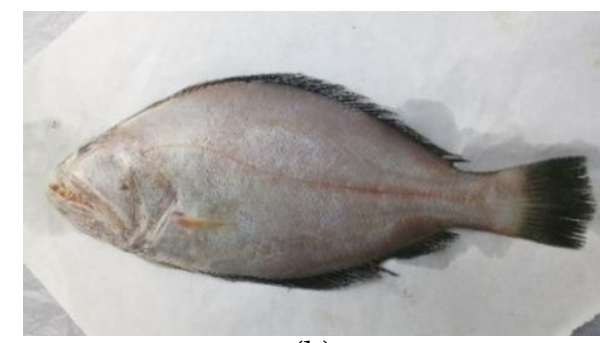

(b)

Gambar 8. Ikan Sebelah (Psettodes erumei) : (a) gambar pengamatan (b) gambar dari fishbase.org

Klasifikasi ikan sebelah menurut fishbase adalah sebagai berikut :

$\begin{array}{ll}\text { Kingdom } & \text { : Animalia } \\ \text { Filum } & \text { : Chordata } \\ \text { Kelas } & \text { : Actinopterygii } \\ \text { Ordo } & \text { : Pleuronectiformes } \\ \text { Famili } & \text { : Psettodidae } \\ \text { Genus } & : \text { Psettodes } \\ \text { Spesies } & : \text { Psettodes erumei }\end{array}$

Barokah et al. (2016) menyatakan bahwalkan Sebelah (Psettodes erumei) merupakan ikan demersal yang hidup di dasar perairan. Berdasarkan hasil yang didapatkan memiliki bentuk tubuh non bilateral simetris dan termasuk ke dalam kelompok ikan yang memiliki bentuk tubuh pipih mendatar. Ikan sebelah memiliki bentuk mulut terminal dan bentuk ekor truncate, Sirip ekor meruncing (pointed) dan memiliki warna badan putih kemerahan. ikan sebelah biasanya hidup di dasar yang dangkal dan mendatar. Biasanya menghabiskan waktunya menggeletak di dasar dengan salah satu sisi tubuhnya menghadap kebawah. Sisi yang menghadap kebawah rata mendatar dan berwarna putih atau sangat pucat, sedangkan sisi yang menghadap keatas bentuknya cembung dan berwarna. Warna tubuh biasanya serasi dengan lingkungan sekitarnya.

Ikan Sebelah belum memberikan kontribusi yang bernilai ekonomis penting, tidak menutup kemungkinan pada masa mendatang bisa dijadikan sebagai komoditas ekspor maupun bahan konsumsi di dalam negeri (Adela et al., 2016).

\subsection{Hasil Pengamatan Ikan Pelagis}

Hasil pengamatan ikan pelagis yang ditemukan pada PPI Kijang antara lain, Ikan Selar (Atule mate) dapat dilihat pada Gambar 9. Ikan Kuwe (Gnathanodon speciosus) dapat dilihat pada Gambar 10. Ikan Bulat (Carangoides plagiotaenia) dapat dilihat pada Gambar 11. Ikan Tongkol (Euthynnus affinis) dapat dilihat pada Gambar 12. Ikan Tenggiri (Scomberomorus comerson) dapat dilihat pada Gambar 13. Ikan Kembung (Rastrelliger kanagurta) dapat dilihat pada Gambar 14. Serta, Ikan Selar Tetengkek/Selikur (Megalaspis cordyla) dapat dilihat pada Gambar 15. 


\subsubsection{Ikan Selar (Atule mate)}

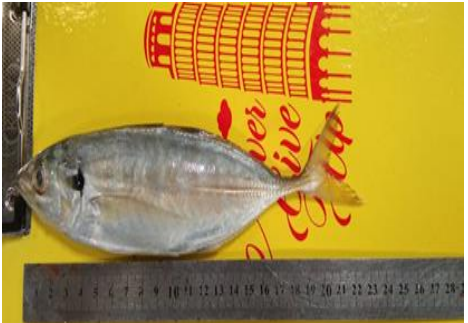

(a)

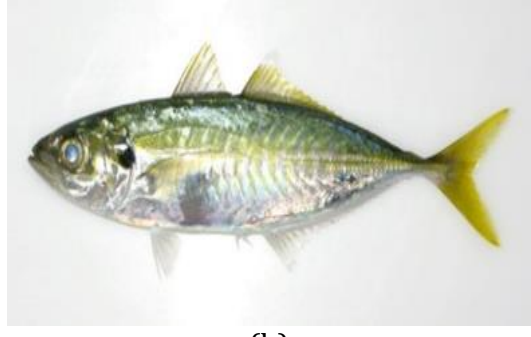

(b)

Gambar 9. Ikan Selar (Atule mate) : (a) Gambar Pengamatan (b) Gambar dari fishbase.org

Klasifikasi ikan selar menurut fishbase yaitu sebagai berikut :

$\begin{array}{ll}\text { Kingdom } & \text { : Animalia } \\ \text { Filum } & \text { : Chordata } \\ \text { Kelas } & \text { : Actinopterygii } \\ \text { Ordo } & \text { : Perciformes } \\ \text { Famili } & : \text { Carangidae } \\ \text { Genus } & : \text { Atule } \\ \text { Spesies } & : \text { Atule mate }\end{array}$

Berdasarkan hasil yang didapat ikan selar memiliki badan bundar memanjang dan agak pipih. Ikan selar memiliki bentuk mulut superior dengan muncung meruncing. Bentuk ekor dari ikan ini adalah cagak dan gurat sisi tampak, warna sirip dan ekornya berwarna kuning keemasan (Kurniawan, 2020; Zahra et al., 2019). Menurut Peristiwady (2006), ikan selar memiliki kepala dan badan yang hijau kekuningan serta keperakan, bagian bawah putih keperakan dan dapat mencapai ukuran $30 \mathrm{~cm}$. Ikan selar memiliki ciri hampir sama dengan ikan selar kuning. Perbedaannya pada ikan selar terdapat pita berwarna hijau membujur mulai dari mata sampai sirip ekor. Ikan selar hidup disekitar perairan pantai dikedalaman 0-50 m, berwarna hijau kekuningan dengan 9 atau 10 garis samar, sirip punggung dan sirip ekor kuning. Harga ikan selar di Pangkalan Pendaratan Ikan yaitu Rp. 38.000,- /kg.

\subsubsection{Ikan Kuwe (Gnathanodon speciosus)}

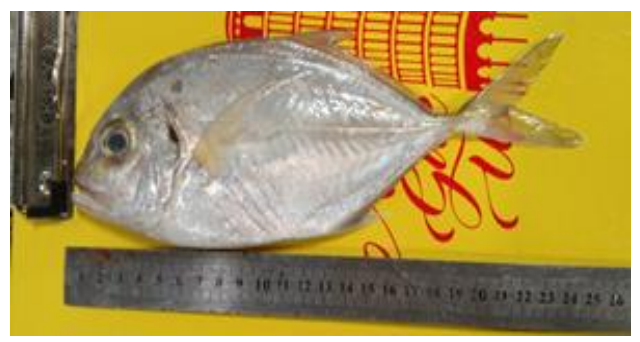

(a)

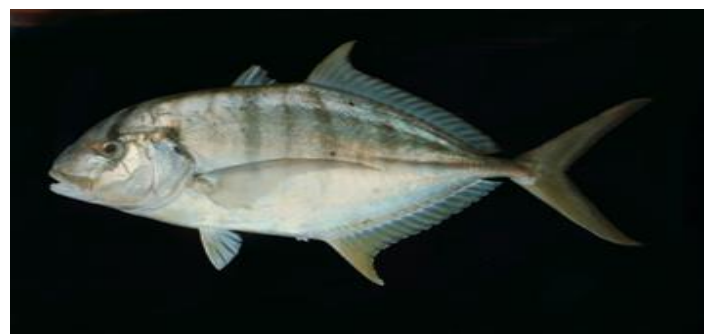

(b)

Gambar 10. Ikan Kuwe (Gnathanodon speciosus) (a) Gambar Pengamatan (b) Gambar dari fishbase.org

Klasifikasi ikan Kuwe menurut fishbase yaitu sebagai berikut.

$\begin{array}{ll}\text { Kingdom } & : \text { Animalia } \\ \text { Filum } & : \text { Chordata } \\ \text { Kelas } & : \text { Actinopterygii } \\ \text { Ordo } & : \text { Perciformes } \\ \text { Famili } & : \text { Carangidae } \\ \text { Genus } & : \text { Gnathanodon } \\ \text { Spesies } & : \text { Gnathanodon speciosus }\end{array}$

Berdasarkan hasil yang didapatkan ikan kuwe berbentuk oval dan pipih. Warnanya bervariasi, yaitu buru bagian atas dan perak hingga keputih-putihan di bagian bawah. Tubuh ditutupi sisik halus berbentuk sikloid. Sisiknya kecil dengan gurat sisi bercabang. Dibagian dada sisiknya berkurang atau tidak ada. Terdapat tiga duri, dua yang pertama terpisah dari sirip yang diam (Tambunan, 2006). Ikan ini biasanya memiliki ciri ciri fisik memiliki sirip punggung berjumlah 9 buah dengan sirip punggung lunak sebanyak 19-22 buah, sirip dubur sebanyak 3 buah dengan sirip dubur lunak sebanyak 14-17 buah (Fitri et al., 2019). Ikan kuwe hidup diperairan dangkal, terumbu karang, membentuk gerombolan kecil. Ukuran ikan ini dapat mencapai $75 \mathrm{~cm}$, umumnya $50 \mathrm{~cm}$. Harga ikan kuwe di Pangkalan Pendaratan Ikan Kijang yaitu Rp. 55.000,-/kg. 


\subsubsection{Ikan Bulat (Carangoides plagiotaenia)}

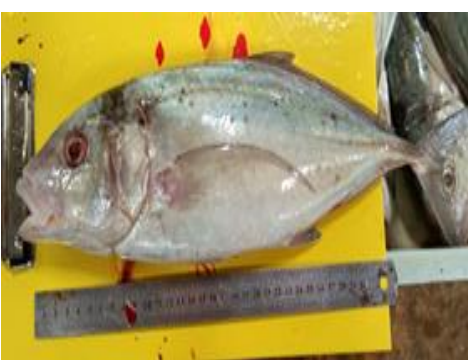

(a)

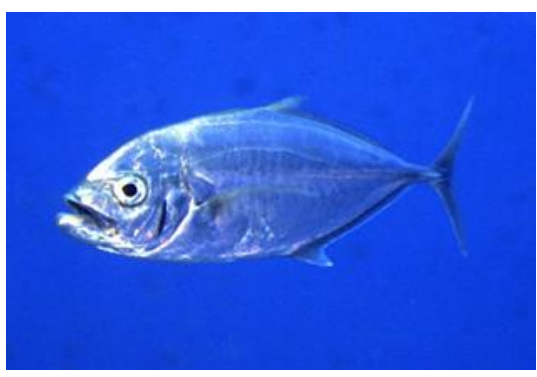

(b)

Gambar 11. Ikan Bulat (Carangoides plagiotaenia) : (a) Gambar Pengamatan (b) Gambar dari fishbase.org

Klasifikasi ikan bulat menurut fishbase yaitu sebagai berikut.

$\begin{array}{ll}\text { Kingdom } & : \text { Animalia } \\ \text { Filum } & \text { : Chordata } \\ \text { Kelas } & : \text { Actinopterygii } \\ \text { Ordo } & : \text { Perciformes } \\ \text { Famili } & : \text { Carangidae } \\ \text { Genus } & : \text { Carangoides } \\ \text { Spesies } & : \text { Carangoides plagiotaenia }\end{array}$

Berdasarkan hasil yang didapat, ikan bulat memiliki badan lonjong dan pipih. Ikan ini memiliki bentuk mulut superior dan bentuk ekor cagak. Gurat sisi tampak, lengkung badan bagian atas agak lebih cembung dari pada bagian bawah. Bagian dada dari ikan ini seluruhnya bersisik. Ikan ini memiliki warna kepala dan bagian badan atas berwarna abu kekuningan. Pada badan bagian bawahnya berwarna abu abu dengan bercak jingga. Harga ikan Bulat di Pangkalan Pendaratan Ikan Kijang yaitu Rp. 38.000,-/kg.

\subsubsection{Ikan Tongkol (Euthynnus affinis)}

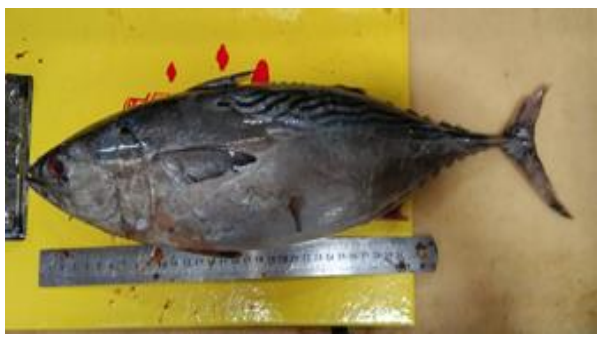

(a)

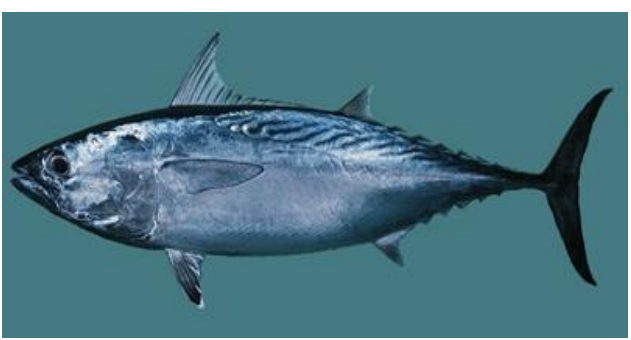

(b)

Gambar 12. Ikan Tongkol (Euthynnus affinis) : (a) Gambar Pengamatan (b) Gambar dari fishbase.org

Klasifikasi ikan tongkol menurut fishbase yaitu sebagai berikut.

$\begin{array}{ll}\text { Kingdom } & : \text { Animalia } \\ \text { Filum } & \text { : Chordata } \\ \text { Kelas } & \text { : Actinopterygii } \\ \text { Ordo } & : \text { Perciformes } \\ \text { Famili } & : \text { Scombridae } \\ \text { Genus } & : \text { Euthynnus } \\ \text { Spesies } & : \text { Euthynns affinis }\end{array}$

Berdasarkan hasil yang didapatkan, ikan tongkol memiliki badan memanjang, bentuk mulut terminal dan bentuk ekor cagak. Ikan ini memiliki bentuk kepala bagian atas sampai awal dasar sirip punggung agak cembung. Ikan tongkol mempunyai bentuk tubuh seperti cerutu dan kulit licin dan tergolong tuna kecil. Sirip dada melengkung dan sirip dubur terdapat sirip tambahan kecil- kecil. Sirip dada pendek, kepala dan badan bagian atas berwarna biru tua kehitaman, sedangkan badan bagian bawah berwarna abu abu keperakan. Sirip perut dan sirip duburnya cenderung berwarna putih. Sirip ekor, sirip dada, dan sirip punggung berwarna kehitaman. Ukuran ikan ini dapat mencapai $100 \mathrm{~cm}$. Hidup bergerombol besar, penangkapan dengan pancing rawai dan dipasarkan dalam bentuk segar. Harga ikan tongkol di Pangkalan Pendaratan Ikan Kijang yaitu Rp. 18.000,-/kg. 


\subsubsection{Ikan Tenggiri (Scomberomorus comerson)}

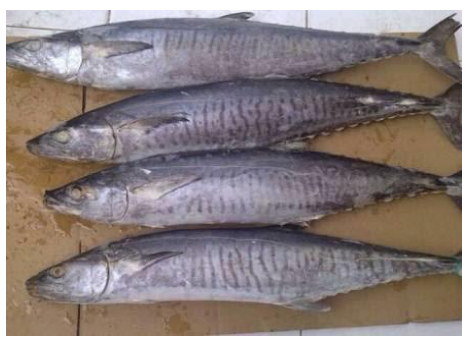

(a)

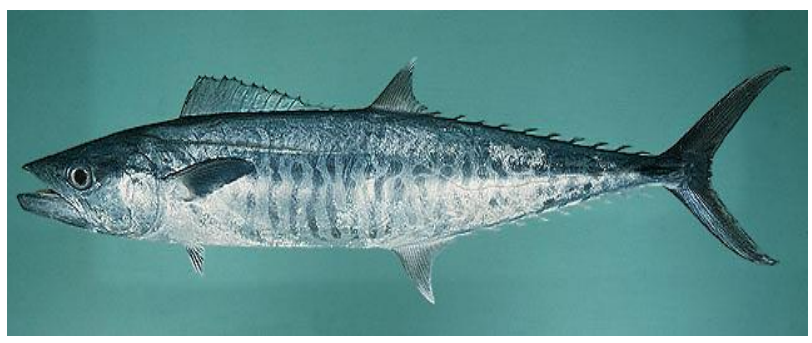

(b)

Gambar 13. IkanTenggiri (Scomberomorus comerson): (a) Gambar Pengamatan (b) Gambar dari fishbase.org.

Klasifikasi ikan tenggiri menurut fishbase yaitu sebagai berikut.

$\begin{array}{ll}\text { Kingdom } & \text { : Animalia } \\ \text { Filum } & \text { : Chordata } \\ \text { Kelas } & \text { : Actinopterygii } \\ \text { Ordo } & \text { : Perciformes } \\ \text { Famili } & : \text { Scombridae } \\ \text { Genus } & : \text { Scomberomorus } \\ \text { Spesies } & : \text { Scomberomorus commerson }\end{array}$

Berdasarkan hasil yang didapatkan, ikan tenggiri memiliki tubuh memanjang, daging kulit licin, tidak memiliki sisik kecuali pada gurat sisi yang kecil, sirip punggung ada dua, letal berdekatan dengan bagian depan. Moncong meruncing dengan mulut lebar dan gigi gigi yang tajam dan kuat di rahang atas dan bawah. Panjang moncongnya lebih pendek dari pada sisi kepala bagian belakang. Bentuk mulut superior dan ekor cagak. Ikan ini memiliki warna punggung kebiru-biruan, pinggiran tubuh dan perut berwarna perak. Jenis ikan ini tergolong ikan yang besar dengan panjang tubuh dapat mencapai $150 \mathrm{~cm}$. ikan tenggiri memiliki sirip dubur sama besar besar dengan sirip punggung yang belakang, dan sebelah belakangnya terdapat sirip tambahan sebanyak 9-10 buah. Sirip ekornya bercagak dua berlekuk dalam dengan kedua ujung sirip siripnya yang panjang (Peristiwady, 2006). Harga ikan Tenggiri di Pangkalan Pendaratan Ikan Kijang yaitu Rp.45.000,-/kg.

\subsubsection{Ikan Kembung (Rastrelliger kanagurta)}
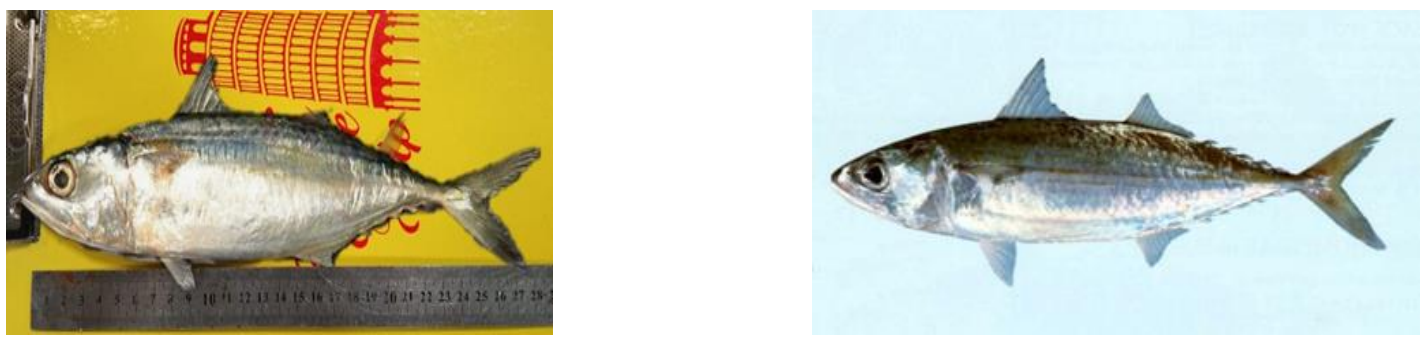

Gambar 14. Ikan Kembung (Rastrelliger kanagurta) : (a) Gambar Pengamatan (b) Gambar dari fishbase.org

Klasifikasi ikan kembung menurut fishbase yaitu sebagai berikut.

$\begin{array}{ll}\text { Kingdom } & \text { : Animalia } \\ \text { Filum } & \text { : Chordata } \\ \text { Kelas } & \text { : Actinopterygii } \\ \text { Ordo } & : \text { Perciformes } \\ \text { Famili } & : \text { Scombridae } \\ \text { Genus } & : \text { Rastrelliger } \\ \text { Spesies } & : \text { Rastrelliger kanagurta }\end{array}$

Berdasarkan hasil yang didapatkan, ikan kembung memiliki badan agak tinggi dan agak pipih. Ikan ini memiliki bentuk mulut terminal dan bentuk ekor cagak. Kepala dan badan bagian atas kehijauan, bagian bawah berwarna putih/abu-abu keperakan. Badan atas memiliki bitnik atau totol berwarna kehitaman memanjang. Sirip punggung dengan bagian tepi kehitaman. Ikan kembung memiliki kepala bagian atas sampai mata hampir lurus, sampai awal dasar sirip punggung agak cembung. Panjang kepala lebih panjang dari pada tinggi badan. Sirip dadanya pendek. Ukuran ikan ini dapat mencapai ukuran $35 \mathrm{~cm}$. Ikan ini memiliki tubuh yang cukup kecil, bersisik dan tidak memiliki sungut (Peristiwady, 2006). Menurut Rahmadani (2017), ikan kembung termasuk ikan yang memiliki nilai ekonomis menengah, ikan ini suka hidup secara bergerombol, hidup diperairan pantai, lepas pantai, pemakan plankton. Harga ikan Kembung di Pangkalan Pendaratan Ikan Kijang yaitu Rp. 27.000,-/kg. 


\subsubsection{Ikan Selar Tetengkek (Megalaspis cordyla)}

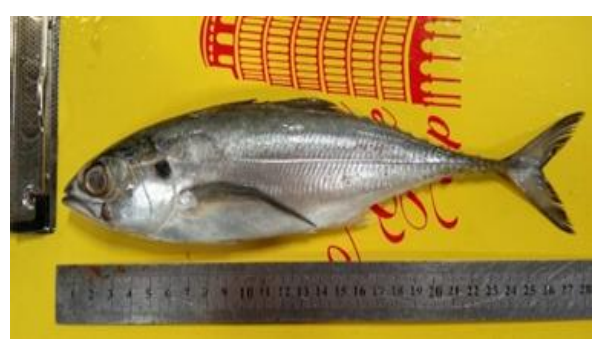

(a)

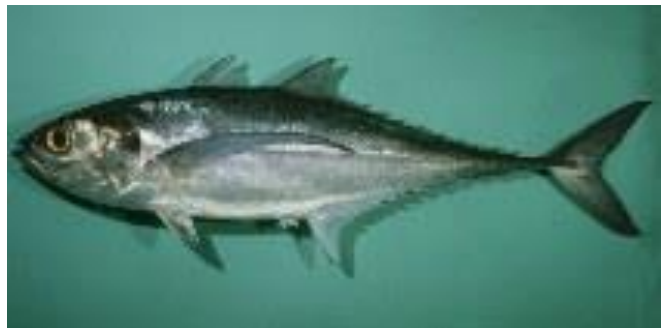

(b)

Gambar 15. Ikan Selar Tetengkek (Megalaspis cordyla) (a) Gambar Pengamatan (b) Gambar dari fishbase.org

Klasifikasi ikan selikur menurut fishbase yaitu sebagai berikut.

$\begin{array}{ll}\text { Kingdom } & : \text { Animalia } \\ \text { Filum } & \text { : Chordata } \\ \text { Kelas } & \text { :Actinopterygii } \\ \text { Ordo } & : \text { Perciformes } \\ \text { Famili } & : \text { Carangidae } \\ \text { Genus } & : \text { Megalaspis } \\ \text { Spesies } & : \text { Megalaspis cordyla }\end{array}$

Ikan selar tetengkek (Megalaspis cordyla) memiliki nama lokal ikan selikur. Berdasarkan hasil yang didapatkan, ikan selar tetengkek memiliki bentuk tubuh bulat memanjang. Bentuk mulut dari ikan ini adalah superior dan bentuk ekornya cagak. Tubuh bulat memanjang, seperti torpedo; dengan moncong meruncing dan tangkai ekor (caudal peduncle) mengecil kokoh. Panjang keseluruhan dapat mencapai $80 \mathrm{~cm}$ (TL, total length), namum umumnya sekitar 30-40 cm; berat dapat mencapai 3-4 kg. Mata berukuran sedang, dengan pelupuk lemak yang berkembang baik menutupi seluruh lingkaran mata kecuali pada suatu celah tegak berpusat pada pupil mata. Rahang atas dengan gigi runcing kecil-kecil, yang sebelah luar sedikit lebih besar; rahang bawah dengan sebaris gigi kecil-kecil. Ujung belakang rahang atas kurang lebih sejajar tengah mata. Sisir saring pada busur insang yang pertama 26-32 buah (termasuk yang mengerdil). Cleithrum (gelangan bahu) halus pada tepiannya, tanpa tonjolan-tonjolan (Smith-Vaniz, 2001).

Ikan ini tergolong ikan pelagis kecil, penangkapan dengan pancing, purse seine, jaring insang dan dipasarkan dalam bentuk segar. Harga ikan selikur di Pangkalan Pendaratan Ikan Kijang yaitu Rp.22.000,-/kg.

\section{SIMPULAN}

Adapun ikan demersal yang di daratkan di Pangkalan Pendaratan Ikan Kijang berjumlah 7 spesies yang terdiri dari : ikan delah (Caesio teres), ikan kurisi (Nemipterus nemurus), ikan pari (Neotrygon kuhlii), ikan manyung (Netuma thalassina), ikan lebam (Siganus guttatus), ikan jebung (Abalistes stellaris), dan ikan sebelah (Psettodes erumei). Ikan pelagis yang ada di Pangkalan Pendaratan Ikan Kijang terdapat 7 spesies yaitu ikan ikan selar (Atule mate), ikan kuwe (Gnathanodon speciosus), ikan bulat (Carangoides plagiotaenia), ikan tongkol (Euthynnus affinis), ikan tenggiri (Scomberomorus comerson), ikan kembung (Rastrellige rkanagurta), dan ikan selar tetengkek (Megalaspis cordyla).

\section{UCAPAN TERIMA KASIH}

Penulis menyampaikan ucapan terimakasih kepada semua pihak yang turut membantu dalam penelitian, terutama kepada orang tua, nelayan, petugas PPI Kijang, dan teman Manajemen Sumberdaya Perairan angkatan 2017 beserta dosen pembimbing.

\section{REFERENSI}

Adela, S., Ghofar, A., \& Djuwito. (2016). Komposisi ikan yang tertangkap dengan cantrang serta aspek biologi ikan sebelah (Psettodes erumei) di TPI Asemdoyong, Pemalang. Journal of Maquares. 5(1): 52-61.

Amalsyah, R., Kasim, M., \& Idris, M. (2019). Daya Ramban (Grazing) Ikan Baronang (Siganus guttatus) yang Dipelihara Dengan Rumput Laut Kappaphycus alvarezii di Perairan Tanjung Tiram, Kabupaten Konawe Selatan. Jurnal Biologi Tropis. 19(2): 309-315.

Barokah, L., Solichin, A., \& Suprapto, D. (2016). Aspek biologi ikan sebelah (Psettodes erumei) yang tertangkap dan didaratkan di Pelabuhan Perikanan Pantai (PPP) Tawang Kabupaten Kendal. Journal of Maquares. 5(4): 216-223.

Carpenter, E.K. (1988). FAO Species Catalogue. FAO Fisheries Synopsis. 125(8): 1-65.

Desiani, R., Susiana, \& Lestari, F. (2019). Tingkat pemanfaatan ikan delah (Caesio teres) pada Perairan Mapur yang didaratkan di Desa Kelong, Kecamatan Bintan Pesisir, Kabupaten Bintan, Indonesia. Jurnal Akuakultur, Pesisir dan Pulau-Pulau Kecil. 3(2): 9-15.

Febriyanti, D. (2015). Total plate count dan staphylococcus aureus pada ikan asin manyung (Arius Thallasinus) di TPI Puger Kabupaten Jember. [Skripsi]. Universitas Jember. Jember.

Fishbase. http.www.fishbase.org 
Fitri, N.H.E., Lestar, F., \& Ulfah, F. (2019). Identifikasi Ikan Lokal di Tempat Pendaratan Ikan dan Pola Pemanfaatan Perikanan di Pulau Alai. Jurnal Akuatiklestari. 2(2): 1-9.

Kinakesti, M.S., \& Wahyudewantoro, G. (2017). Kajian jenis ikan pari (Dasyatidae) di Indonesia. Jurnal Fauna Indonesia. $16(2)$ : $17-25$.

Kurniawan, D. (2020). Pendugaan Stok Ikan Selar (Atule mate) di Perairan Kabupaten Pangkajene dan Kepulauan, Sulawesi Selatan. Jurnal Akuatiklestari. 3(2): 35-42.

Peristiwady, T. (2006). Ikan-Ikan Laut Ekonomis Penting di Indonesia. Petunjuk Identifikasi. Lembaga IlmuPengetahuan Indonesia. Jakarta.

Puckridge, M., Last, P.R., White, W.T., \& Andreakis, N. (2013). Phylogeography of the Indo-West Pacific maskrays (Dasyatidae, Neotrygon): A complex example of chondrichthyan radiation in the Cenozoic. Jurnal Ecology. 3:21-32.

Rahayu, S.E. (2012). Kajian stok sumberdaya ikan kurisi (Nemipterus japonicus, Bloch 1791) di perairan selat Sunda yang didaratkan di PPI Labuan, Pandeglang, Banten. [Skripsi]. Institut Pertanian Bogor. Bogor.

Rahmadani, R. (2017). Kajian Kandungan Beberapa Logam Berat Pada IkanKembung (Rastrelliger kanagurta) Di Pesisir Teluk Lampung Secara Spektrofotometri Serapan Atom. [Skripsi]. Universitas Lampung. Bandar Lampung.

Rosmatun, S.M. (1997). Budidaya Udang Windu dan Ikan, Edisi ke 10. Penebar Swadaya. Jakarta.

RPJMD Kabupaten Bintan. (2016). Gambaran Umum Wilayah Kabupaten Bintan 2016-2021. Bintan.

Smith-Vaniz, W.F. (2001). Megalaspis cordyla. in Kent E. Carpenter \& Volker H. Niem (Eds.). FAO Species Identification Guide: The Living Marine Resources of The Western Pacific. Vol. 4 Bony fishes part 2 (Mugilidae to Carangidae): 2726. Food and Agriculture Organization, Rome.

Tambunan, P. (2006). Ikan-Ikan Laut Pelagis dan Demersal. Departemen Kelautan dan Perikanan. Jakarta.

Taunay, N.P., Wibowo, E., \& Redjeki, S. (2013). Studi komposisi isi lambung dan kondisi morfometri untuk mengetahui kebiasaan makan ikan manyung (Arius thalassinus) yang diperoleh di wilayah Semarang. Journal of Marine Research. 2(1) : 87-9.

Triharyuni, S., Hartati, T.S., \& Anggawangsa, F.R. (2013). Produktivitas dan kerentanan ikan kurisi (Nemipterus spp.) hasil tangkapan cantrang di laut Jawa. Jurnal Litbang. 19(4) : 213-220.

Zahra, A.N.A., Susiana, \& Kurniawan, D. (2019). Potensi lestari dan tingkat pemanfaatan ikan selar (Atule mate) yang didaratkan di Desa Kelong, Kabupaten Bintan, Indonesia. Jurnal Akuakultur, Pesisir dan Pulau-Pulau Kecil. 3(2): 57-63.

Zarry, M.G., Hambal, M., \& Zuhrawaty, N.A. (2017). Identifikasi endoparasit pada ikan jebong (Abalistes stellaris) di tempat pelelangan ikan (TPI) Lampulo kota Banda Aceh. Jurnal Ilmiah Mahasiswa Veteriner. 1(2): 188-195. 